\title{
MORAL IMPLICATIONS OF AUGUSTINE'S PHILOSOPHICAL AND SPIRITUAL JOURNEY IN HIS CONFESSIONES
}

\begin{abstract}
Aurelius Augustinus, though born to a Christian mother, had undergone a long and tedious spiritual journey in his search for truth and meaning. Youthful hedonism gave way to Skepticism, Manichaeism, and later on to Neo-Platonism as he searched for answers to some of the most pressing existential questions of mankind. Platonism, above all, proved to be (in its renewed, mystical form of Neo-Platonism) the most influential factor in his spiritual and intellectual journey. What we see in Augustine, in his personal struggle with philosophical ideas and religious cults that allowed him to become one of the most influential Christian philosopher of all times, is an interesting combination of a 'MacIntyrean' focus on the socially embodied reality of historical traditions and a 'Kierkegaardian' emphasis on the individual inner processing of the transcendental, the 'inwardness' of the human self, and the individual's responsibility before God.
\end{abstract}

Keywords: Augustine, Neo-Platonism, Manichaeism, MacIntyre, Tradition, Confessions, Human Moral Identity, Kierkegaard.

\section{Introduction}

Saint Augustine was a man of exceptional intellect who came to be known as the most influential Christian philosopher in the ancient West and whose relevance in the areas of religion, philosophy, and ethics remains strong even to this day [1]. His ideas, e.g. his view that people are naturally social, his thoughts on the Trinity, and his conception of the agency of human will, belong to his lasting contributions to Western Civilization [2]. It is often overlooked, however, that his was a journey full of doubts and intellectual struggles and that he became "the" philosopher of the West not by any one person or experience, but from a lifetime of religious evolution and philosophical questioning. In his search for truth, goodness, and meaning in the world, he learned by experience of many different religious sects and schools of philosophy before coming back to the comprehensive outlook on life represented by the so-called "Western Catholicism." Though he was brought up in a Christian environment as a child, it was the years of experimenting with philosophical ideas and religious cults that allowed him to become a true, informed believer and a Christian philosopher. To answer the questions of how can philosophy and ethics benefit today from his ideas, one must take a look at the three main strands of thought in Augustine's life before his crossing over from philosophical paganism to
Christian philosophy and theology: Manichaeism, Neoplatonism, and Paulinism. The primary source of scrutiny will be his own autobiography - the Confessions (Confessiones).

\section{Early Influences: Toward the Search of True Wisdom}

Aurelius Augustinus (commonly known as St. Augustine) was born in 354 in Tagaste, North Africa (Algeria), during the reign of the Roman Empire. His mother was a devout Christian, his father was a Pagan though he later became a Christian [3]. He was born to ambitious parents who wished him to pursue the life a rhetorician, a "phrase salesman" [4]. Augustine had a brilliant mind and he excelled in his studies (first in Tagaste and later in Carthage), studying rhetoric and law. At the age of eighteen, Augustine was directed to read Hortensius in order that he would learn formally from its literary style. He was instead inspired by its contents and emphases, primarily that of living a philosophical life in a relentless search for wisdom and truth [3, p. 70]. This started his journey into philosophy and religion, which was to become his passion throughout his life.

\footnotetext{
* ${ }^{1}$ Michal Valco, ${ }^{2}$ Roman Kralik, ${ }^{3}$ Lee Barrett

${ }^{1}$ Department of Religious Studies, Faculty of Humanities, University of Zilina, Slovakia

${ }^{2}$ Department of General and Applied Ethics, Faculty of Arts, Constantine the Philosopher University, Nitra, Slovakia

${ }^{3}$ Professor of Theology at Lancaster Theological Seminary, Lancaster, USA

E-mail: michal.valco@fhv.uniza.sk
} 


\section{The 'Manichean' Stage}

Instead of Christianity, Augustine chose to look for wisdom and truth in Manichaeism, which he considered to be a more sophisticated version of the Christian religion. Manichaeism was a heretical form of Christianity that ensnared Augustine and many others like him. For nine years Augustine "descended into comradeship with the pride-maddened sensualists, the prattlers, whose words spread the devil's nets and mixed a trapper's lime made up of garbled versions of the names of Jesus Christ and the Supporter-names always on their lips, sounds on their tongues, without meaning in their hearts" [4, p. 47].

For Augustine, despite the lack of truth, Manichaeism satiated his pride and allowed him to continue his pursuit of fame and earthly pleasures. "A brief anger had often invested him but he had never been able to make it an abiding passion and had always felt himself passing out of it as if his very body were being divested with ease of some outer skin or peel. He had felt a subtle, dark and murmurous presence penetrate his being and fire him with a brief iniquitous lust: it too had slipped beyond his grasp leaving his mind lucid and indifferent. This, it seemed, was the only love and that the only hate his soul would harbour" [3, p. 40]. As the spark of divine creation that Augustine and the other Manicheans classified themselves, he and the other followers were not responsible for any of the earthly sins they committed. Any wrong they did could simply be blamed on their tainted earthly body.

\section{Almost a Christian: The Neo-Platonic Stage}

Eventually he came to a realization that the teachings of the Manicheans were merely a reflection of a worldly wisdom that provided the mere illusion of true happiness and hope. In addition to that, while in Milan (Italy), Augustine found interest in the company of the great Catholic bishop Ambrose. Though he respected and even admired the man greatly, Ambrose did not exert enough influence to completely convert Augustine to Catholicism. His spiritual and intellectual search led him to explore the thoughts of the academic skeptics and the ideas of astrology, before he found his next inspiration in a form of mystical Platonism that differed from the skepticism of the Academy. Nevertheless, Ambrose came to play an indispensable role in Augustine's intellectual and spiritual progress. Augustine praises him as one who "assumed a father's role toward me, to guide my wanderings with a bishop's loving care” [4, p. 103] Though originally determined to focus on the rhetoric style of Ambrose's preaching, he soon admitted that "he simply seemed not to be talking nonsense, so I could hold that the Catholic faith was not as helpless against the Manichaean critique as I had thought it" [4, p. 104].

\section{The 'Pauline-Ambrosian' Influence: Searching for the 'Embodied' Truth}

There was, however, something missing in Neo-Platonism that Augustine had always valued greatly, if not explicitly, then most certainly implicitly: the notion of Jesus Christ. Augustine wrote, "I did read there [i.e., in the Platonist writings] that the Word, God, 'is not born from flesh, or blood, or human desire, or of fleshly desire, but from God.' But I did not read there: 'The word became flesh, to live with us."' [4, p. 147]. Both the Platonists and the Christian New Testament shared that statement; John the Apostle and Paul the Apostle expanded and built on that notion. What was lacking was Jesus' atoning sacrifice; the loss of divine security and the bliss of immortality for the sake of God's fallen creatures. Augustine notices that the Platonists speak of Jesus as being "before all time and above all time unchangeably present in eternity with [God], and the bliss of all souls 'is derived from his overflow" [4, p. 148]. Yet they fail to mention that Christ died for sinners or that he was sacrificed for the sake of the weak. Eventually, while in Milan, under the influence of Bishop Ambrose's teachings, Augustine had overcome all intellectual barriers to properly comprehending and embracing the Christian worldview.

\section{Reflections on the Past - Ethical Implications for the Present}

When deliberating the possible moral implications of Augustine's legacy today, one cannot overlook its appeal to what MacIntyre criticizes as the "moral emotivism" of postEnlightenment moral philosophy, in which philosophy abandons its teleological structure and becomes nothing but a forum of inexplicably subjective rules and principles [5, p. 16n; 6, p. 173], wherein "all being esse - the created realm as well as the Creator - remain purely on the cogito level as a mere content of human consciousness" [7, p. 55]. Could Augustine with his potent, subjective, experiential epistemology suggested by his personal search for truth, be seen as a forerunner of this trend? After all, Augustine sets out, as the very first significant author in ancient times, to biographically and psychologically analyze his search for truth, i.e. value, meaning, significance (on both the personal, as well as metaphysical level) [8]. Doesn't his personal history (youthful hedonism, Skepticism, Manichaeism, Neo-Platonism, Paulinism) marked by "emotivistic outbursts" of his troubled conscience, or an inner light that illumines the mind [9], constitute the sole basis upon which he arrives at "the truth"?

We should not be easily led astray to think so. Morality and values (both moral and spiritual) are integral parts of human communities - they are necessarily (by definition) socially embodied, not individually based. There is no "self-abstraction" of the conscious self here! We cannot abstract ourselves from 
who we are. This is why Augustine put such a high emphasis on the reality and the witness of the embodied communities of faith (the ecclesia visibilis of his time). Augustine's discontent with the philosophical sects was in part a discontent with their elitist abstraction from broader communities and their reliance upon individual will-power and the individual's exercise of rational reflection. Augustine was convinced that there is an organic solidarity to the human race, whereby the original humans stand as the physical, social, intellectual, psychological, moral, and spiritual representatives of all humanity at all times and in all places. He drew on several Biblical passages to demonstrate this, such as: (Romans 3:23; Romans 5; Romans 6:6, 16-17, 19; etc.). One can never rid himself of this communal heritage, nor from her responsibility to other humans, or even to the rest of the creation [10, pp. 234-236].

Thus, for Augustine, much like for MacIntyre, virtues can only be understood in terms of their relation to the historic community in which they arise. In his After Virtue, MacIntyre asserts his conviction that in order to understand who we are we must understand where we come from as products of a living, historic tradition:

"A central thesis then begins to emerge: man is in his actions and practice, as well as in his fictions, essentially a storytelling animal. He is not essentially, but becomes through his history, a teller of stories that aspire to truth. But the key question for men is not about their own authorship; I can only answer the question, 'What am I to do?' if I can answer the prior question, 'Of what story or stories do I find myself a part?' ...” [5, p. 216].

If, indeed, it is true that being human essentially means being "a story-telling animal," this implies that our personal stories arise out of tangible, historically embodied narratives (as living traditions) which themselves are dynamic, evolving narratives, influencing others and being influenced by others. MacIntyre continues:

"I am what I may justifiably be taken by others to be in the course of living out a story that runs from my birth to my death; ... I am not only accountable [as subject], I am one who can always ask others for an account, who can put others to the question. I am part of their story, as they are part of mine. The narrative of any one life is part of an interlocking set of narratives....” [5, pp. 217-220 passim]

In contrast to a self-enclosed monad, each human being is endowed with a "moral starting point" that steers him/her to certain goals and practices and away from others. Of utmost importance, then, is for one to be aware of the particular traditional narrative that (to a large extent) constitutes his identity and to carry on the moral and philosophical argument about the "goods which constitute that tradition." MacIntyre proposes:

"Hence what is good for me has to be the good for one who inhabits these roles... These constitute the given of my life, my moral starting point... A living tradition then is an historically extended, socially embodied argument, and an argument precisely in part about the goods which constitute that tradition." [5, pp. 220-222 passim]

This can be and should be understood in line with Augustine's theological/philosophical reasoning [11]. What Augustine came to call the "Christian life" is never the attribute of an individual (and his emotivist, inquisitive capacities) but rather a social life, a community of people with "one heart and one mind" towards God (Acts 4:32). Upon his return to Africa in 388 (after his conversion), he decided to establish a closely-knit community of family members and like-minded friends to contemplate and write about the virtuous life as the fruit of the Christian life. Much of his strength later on (after he had become the bishop of Hippo Rhegius) was spent in disputes concerning the true nature of the church as a forgiven community of sinners with the Donatist schismatics. Augustine knew that it was this community of people that "constituted the given of [his] life, [his] moral starting point," not his subjective, emotivistic outbursts or private experiences. It is precisely this lack of communal identity, this impoverished and thin spiritual narrative, which is reflected in the most recent scientific studies on the effects of religion (Christianity) on morality. Wilhelm Hofmann [et al.] in his recently published article in the Science magazine argued that religious and nonreligious participants in their survey did not differ in the quality or frequency of committed moral and immoral acts [12]. The most probable reason for this somewhat surprising lack of difference in the quality and likelihood of moral actions between religious and nonreligious persons is the overly subjectivist, socially-detached, and irregularly practiced religious identity [13]. "The quest for truth, at least the truth about the most important things, cannot be divorced from the quest to become the kind of person we need to become" [14, p. 26] - and the one, truly viable context for practicing once religious identity is within the community that shares the same meta-narrative [15]. This is further confirmed by recent ethical and socio-pedagogical studies claiming a decisive importance of family and social interactions in constituting moral character. Thus Cabanova points out that a "rudimentary base of attitudes is represented by a trans-generational transfer of values through the way of life in a family..." reflecting not only one's family situation but also that "of various social communities in an environment where young people can be found" $[16$, p. 4 ; 17].

On the other hand, one should not neglect one's own, personal history, including the subjective, experiential dimensions [13]. One extreme can easily be substituted with another, equally illegitimate and detrimental when one neglects the individual. What we can find in Augustine is a "happy blend" of the communitarian (MacIntyre) with the individual - such as we see for example in Kierkegaard (19 $9^{\text {th }}$ century) [18]. It was Kierkegaard who warned against the loss of the individual in the mob of the state church [19 and 20]. Kierkegaard feared that Christendom, the alliance of church, state, and middle-class culture, had falsely given the 
impression that one can have genuine faith simply by adhering to the norms of the allegedly Christian society, without undergoing a true transformation of one's passional life. For Kierkegaard, Christendom bred the false and spiritually lethal attitude that faith is a matter of mere conformity. This attitude generated smugness, complacency, and militated against any passionate desire to be inwardly transformed. In fact, Kierkegaard's emphasis on the role that passion and inwardness of the human subject play in the acquisition of religious truth and in the living out of that truth may be considered one of Kierkegaard's most important and enduring contributions [17]. This emphasis on genuine, heart-felt passion and personal commitment is not unlike Augustine's concern for the development of his own spirituality that is so evident in his Confessions.

Like Augustine, Kierkegaard did not discount the role that a tradition-bearing community plays in the cultivation of an individual's inwardness. He was well aware that the doctrines, liturgies, and prayers of the Lutheran church had shaped his own piety, and he continued to value these communal practices. Kierkegaard's Discourses for the Communion of Fridays show how important the worshipping life of the church was for him. Making this attachment to the teachings of the church explicit, his pseudonym Johannes Climacus insisted in Concluding Unscientific Postscript that Christianity presupposes not only a "how" (the life of passionate faith), but also a definite "what" (communally mediated doctrines and concepts) that makes the "how" of inwardness possible. The passion of faith requires the internalization of communal convictions and values. Kierkegaard's basic complaint with the church was that it had ceased to make it clear that Christian concepts must be appropriated by individuals with personal passion and commitment. He saw his task as reintroducing the struggle and passion of personal transformation back into the lives of the individuals who constitute the community.

So what we see in Augustine's thought, on the one hand, a Kierkegaardian passionate inwardness and self-reflection but, on the other hand, also an unswerving emphasis on the community of the visible church as the embodiment of the "tradition" that is foundational for one's identity. It is an interesting combination of a "MacIntyrean" focus on the socially embodied reality of historical traditions and a "Kierkegaardian" emphasis on the individual's inner processing of the encounter with transcendence, the "inwardness" of the human self, and the individual's responsibility before God. Such perspective allows us to draw the following implications:

1) The path to an authentic subjectivity seems to lead inevitably through the complicated and sometimes painful struggles of life. One should not expect to make sense of his own life without an arduous struggle to interpret one's existence in relation to self, the world, and to God. The power and wisdom of such interpretation (of one's experience) comes from God as the source, guide, and goal of the journey [8, p. 380].

2) Authentic subjectivity should be understood in its "dialectical relationship with the historical objectivity of God's economy of salvation, including the communal nature of Christian faith." [21, p. 294] The turn to the subject in epistemology, cultural life, and ethics avoids the seemingly inescapable detrimental consequences of the multidimensional fragmentation of our postmodern world [22] only if the individual subject is anchored horizontally (in the social fabric of his community) and vertically (in the transcendent and yet fiercely immanent narrative of divine self-revelation in the acts of creation, redemption, and sanctification). The meaning of life cannot be truly understood apart from narrative ethics' interpretation of the doctrine of creation and redemption. An "emptyshell" up-rooted identity "becomes a threat to the level of ethics, which happens to be guaranteed by the freedom and responsibility of a continuously understood, concrete You” [22, p. 75] and inevitably spawns a cultural meltdown, dragging "Europe into a deep crisis." [23, p. 96]

3) In addition to that, the development of character integrity must remember the organic nature of moral experience [24]. As Thompson rightly argues, "failure to recognize the historically situated character of moral inquiry ... has resulted in a failure to recognize that much of our contemporary terms and tools of moral analyses are remnants from previous contexts of inquiry which are no longer mutually agreed upon nor recognized as relevant.” [24, p.12]

4) MacIntyre failed to acknowledge the triune history of salvation as foundational for "the narrative quality of Augustine's account.” [24, p. 12] Thus, we agree with Thompson that a "more explicit recognition of the theology of creation, of the Creator and Redeemer as the source of Thomistic esse, might have brought to the surface the methodological requirements of a sound narrative ethics and would, in turn, help further the conversation in insightful ways." [24, p. 12]

5) This search for a new anchor of human identity and experience offers something deeper and more radical than political allegiances. It offers an existential anchor in the universal order of things that will bring about a new quality of relationships among human beings, a new quality of human mutuality, in which the human individual will cease to be a mere instrument on the path of other's success. Individuals are thus more clearly seen as genuinely irreducible to the political (totalitarian, or not) order.

6) An authentic character formation involves more than mere conveyance of information. Its ultimate goal should be a spiritual transformation of the reader, which will prevent an aesthetic appeal to fleeting passions and an ethical appeal to limited human reason from overriding the decision-making of the responsible self on its path to the freedom and joy of true faith. "The attempt to communicate an existential truth must 
be sensitive to the fact that the desired understanding and the passional process through which it is acquired are essentially linked" [18].
7) We can thus agree with Evans that the omnipresent skepticism of the present (post-modern) era "cannot be refuted by argument" but only by a voluntary decision "not to be skeptics," since skepticism "is rooted in the will and therefore can only be cured by a transformation of the will" $[14$, p. 26].

\section{References}

[1] QUINN, P. L.: Conception Set forth by John, A., Locke, I. K., Søren Kierkegaard, S., \& Swinburne, R. (1st ed., 1997). P. L. QUINN. A Companion to Philosophy of Religion, 2nd ed. Blackwell Publishing Company, 2010, p. 614. ISBN 978-1-4051-6357-6. As Quinn rightly points out: "The doctrine of original sin ... [and its] interpretation of the Pauline texts worked out by Augustine of Hippo in the course of his controversy with the Pelagians has had an enormous influence on Western Christianity."

[2] The Encyclopedia of Christianity, vol. 1. Edited by Erwin Fahlbusch, et al. Grand Rapids: Eerdmans; Leiden: Brill, 1999, p. 160-161. ISBN 0802824137.

[3] BROWN, P.: Augustine of Hippo: A Biography. Berkley - Los Angeles: University of California Press, 2000, p. 7, ISBN 0-520-22757-3.

[4] AUGUSTINE: St. Confessions. New York: Penguin, 2006, p. xi. ISBN 0143039512.

[5] MACINTYRE, A.: After Virtue. A Study in Moral Theory. $3^{\text {rd }}$ ed., Notre Dame: University of Notre Dame Press, 2007, p. 16.

[6] KONDRLA, P.: Clovek v (post)modernej spolocnosti [Human Being in a (Post)Modern Society]. Search of Meaning: Current Topics in Philosophy and Religion. Ljubljana: KUD Apokalipsa, 2014, pp. 173-191. ISBN 978-961-6894-37-1.

[7] PETRO, M.: Reflexia na prvu kapitolu knihy Jana Pavla II. Pamat a identita - Miera vymedzena zlu [Reflections on the First Chapter of John Paul II's Book 'Memory and Identity' - The Scope Allotted to Evil], Hriech v dnesnom svete - Proc. of students scientific conference. Presov: PETRA, n. o., 2005, pp. 54-57, ISBN 80-89007-61-9.

[8] BARRETT, L. C.: Eros and Self-Emptying: The Intersections of Augustine and Kierkegaard. Wm. B. Eerdmans Publishing, 2013.

[9] CARY, P.: Augustine's Invention of the Inner Self: The Legacy of a Christian Platonist. Oxford: Oxford University Press, 2000.

[10] STEFECEK, J., BRAVENA, N., MAHRIK, T.: Ethical Bridges: Interdisciplinary Insights into Ethical Challenges of Contemporary Philosophy, Theology and Technology, Toronto : Kierkegaard Circle, 2011, ISBN 978-0-9809365-6-8.

[11] Yet, we share some reservations concerning MacIntyre's ability to fully appreciate "how Augustine's reflections were situated within certain theological considerations," especially those of "the relationships between the nature of the created order and the problems of the perverted will" [24, p. 12].

[12] HOFMANN, W., WISNESKI, D. C., BRANDT, M. J., SKITKA, L. J.: Morality in Everyday Life. Science 12 September $2014:$ 345 (6202), 1340-1343. [DOI:10.1126/science.1251560]. According to this study, a respondent's worldview (religious or secular) influenced the kind of event reported and the frequency, but not the likelihood or quality of committed moral and immoral acts.

[13] HAJKO, D.: K premenam civilizacno-kulturnych hodnot v obdobi globalizacie [Concerning the Changes of Civilizational and Cultural Values in the Age of Globalization]. Proc. of interdisciplinary scientific conference Hodnotove aspekty sucasneho sveta, Nitra: KF FF UKF, 2003, pp. 34-42. Following the lead of Hans Kung and Samuel Huntington, Hajko claims that a robust cultivation of moral character and religious identity remain in the time of a global crisis (fragmentation of values) foundational and constitutive cultural and civilizational elements today. Ibid., p. 35.

[14] EVANS, S.: Why Kierkegaard Still Matters - and Matters to Me. Why Kierkegaard Matters: A Festschrift in Honor of Robert L. Perkins. Robert L. Perkins, Marc Alan Jolley \& Edmon L. Rowell (eds.), Mercer University Press, 2010.

[15] For the importance of "narrative teaching" (or, storytelling in the classroom), see: FISHER, R.: Stories for thinking: Developing critical literacy through the use of narrative. Analytic Teaching, 1998, 18.1.

[16] CABANOVA, V.: Social Attitudes and Values of Young People in the Context of Multicultural Education. Communications Scientific Letters of the University of Zilina, No. 3, 2014, 4-8, ISSN 1335-4205.

[17] SHWEDER, R. A.: In Defense of Moral Realism: Reply to Gabennesch. Child Development 61.6 (1990): 2060-2067.

[18] BARRETT, L. C.: Augustine and Kierkegaard-Conjunction or Disjunction. A Lecture presented at the Kierkegaard and Augustine Seminar. St. Olaf College, July 8, 2014.

[19] KIERKEGAARD, S.: Fear and Trembling. The Book on Adler. Trans. Walter Lowrie. New York: London: Toronto: Alfred A. Knopf, 1994. In his Fear and Trembling, Kierkegaard calls for an "uncompromising faith, the tormented acceptance of the demands of the absolute in 'imitation of Christ"' [Ibid., p. xi-xii]. 


\section{COMMNICOIIIONS}

[20] "Faith must not be satisfied with incomprehensibility, because the very relation to or repulsion from the incomprehensible, the absurd, is the expression for the passion of faith.” KIERKEGAARD, S.: Concluding Unscientific Postscript to Philosophical Fragments: A Mimical-Pathetical-Dialectical Compilation, An Existential Contribution, vol. 1, Trans. Howard V. Hong and Edna H. Hong. Princeton: Princeton University Press, 1992, p. 611.

[21] VALCOVA, K.: The Nature and Context of Christian Faith in the World of Post-Christendom: A Critical Appropriation of Kierkegaard's Legacy (in Slovak). In: Kierkegaard and Existential Turn = Kierkegaard a existencialny obrat. Toronto: Kierkegaard Circle \& Central European Research Institute of Soren Kierkegaard, 2014, (Acta Kierkegaardiana supplement, vol. 4), pp. 284-296.

[22] BROSINGER, Z.: Postmoderne variacie identity v etickych vyzvach 21. storocia [Postmodern Variations of Identity in Ethical Challenges of the $21^{\text {st }}$ Century]. Search of Meaning: Current Topics in Philosophy and Religion. Ljubljana: KUD Apokalipsa, 2014, pp. 75-87. ISBN 978-961-6894-37-1.

[23] PETRO, M.: Clovek ako osoba - nadej pre Europu [Human Being as a Person - Hope for Europe]. In: Dancak, P. (ed.): Sapiencialny charakter antropologie Jana Pavla II. v kontexte europskej integracie. Presov: PU v Presove: GTF KFR, 2006, s. 96-111. ISBN 80-8268-571-1.

[24] THOMPSON, C. J.: Christian Doctrine, Christian identity: Augustine and the Narratives of Character, University Press of America, 1999. 